\title{
Renewable Porous Carbons Prepared by KOH Activation as Oxygen Reduction Electrocatalysts
}

\author{
HE Wang-Tao ${ }^{1,2}$, MA Ru-Guang ${ }^{2}$, ZHU Yu-Fang ${ }^{1}$, YANG Ming-Jie ${ }^{3}$, WANG Jia-Cheng ${ }^{2}$ \\ (1. School of Materials Science and Engineering, University of Shanghai for Science and Technology, Shanghai 200093, China; \\ 2. State Key Laboratory of High Performance Ceramics and Superfine Microstructure, Shanghai Institute of Ceramics, Chinese \\ Academy of Sciences, Shanghai 200050, China; 3. Department of Chemical Engineering, Monash University, Victoria 3800, \\ Australia)
}

\begin{abstract}
The nitrogen-doped porous carbon applied for oxygen reduction reaction (ORR) has aroused extensive interests due to its unique physical and chemical properties. However, the complicated nitrogen-doping strategy and high cost limit its extensive application. In this work, a series of nitrogen-doped porous carbons were prepared by a facile pyrolysis process coupling with subsequent $\mathrm{KOH}$ activation using renewable N-enriched biomass potato as carbon source. Effects of activation temperature and $\mathrm{KOH}$ amounts on the textural properties and electrocatalytic ORR activities of the final samples were investigated in detail. The $\mathrm{KOH}$ activation treatment results in a high specific surface area (SSA) and hierarchical porous structure, which is beneficial for improved ORR performance. The optimized NPC-750 possesses a high SSA of $1134.2 \mathrm{~m}^{2} \cdot \mathrm{g}^{-1}$, developed hierarchical pores as well as moderate nitrogen content $(1.57 \mathrm{at} \%)$. It also exhibits a positive onset potential of $0.89 \mathrm{~V}$ ( $v s$. RHE) and half-wave potential of $0.79 \mathrm{~V}$ (vs. RHE). Simultaneously, the advanced long-time stability and methanol-tolerance capacity were also obtained, implying that these biomass-derived porous carbons are potential low-cost ORR electrocatalysts. Moreover, these porous carbons show great potential in various fields including supercapacitors, adsorption/separation, catalysis and batteries as well.
\end{abstract}

Key words: biomass; porous; nitrogen-doped carbons; $\mathrm{KOH}$ activation; oxygen reduction reaction

The low kinetics of oxygen reduction reaction (ORR) on the cathode is a main barrier for the commercial protonexchange membrane fuel cells (PEMFCs) ${ }^{[1-2]}$. Pt is generally considered as one of the best catalysts towards ORR. However, high-cost and low stability limits its widespread application ${ }^{[3-5]}$. Therefore, it is urgent to find new low-cost and high activity alternatives for Pt-based catalysts. Recently, nitrogen-doped porous carbon materials (NPCs) have been recognized as a promising type of ORR catalyst for PEMFCs ${ }^{[6]}$. The carbon matrix possesses excellent electrical conductivity and stability which can promote electronic transmission process during $\mathrm{ORR}^{[7]}$. On the other hand, the introduction of nitrogen atoms can create more active sites due to the changes of electron structure of carbon framework, leading to improvement of catalytic performance towards $\mathrm{ORR}^{[8-10]}$.

Recently, the use of agricultural by-products as precursor materials to prepare nitrogen-doped carbons at- tracted much attention ${ }^{[11-13]}$. Precursor materials have lots of advantages such as environment-friendliness, low-cost and abundance on the earth. Moreover, there are various hetero-elements such as $\mathrm{N}, \mathrm{S}, \mathrm{Fe}$, etc in biomass materials $^{[14-15]}$. Therefore, it is convenient to obtain nitrogendoped carbons by direct pyrolysis of biomass materials without additional nitrogen sources ${ }^{[16]}$. However, the specific surface area (SSA) and porosity of nitrogen doped carbons obtained from simply pyrolysis of biomass materials are too low to match the demand of exposing enough active sites, leading to poor electrochemical performance ${ }^{[17-18]}$. Thus, it is highly desirable to improve the SSA and porosity of nitrogen doped carbons derived from biomass.

To our knowledge, there are various activating agents and templates applied in preparation of porous carbons with high SSA and high porosity, such as $\mathrm{CO}_{2}, \mathrm{ZnCl}_{2}$, $\mathrm{KOH}, \mathrm{H}_{3} \mathrm{PO}_{4}$ and $\mathrm{SiO}_{2}{ }^{[19-23]}$. In particular, $\mathrm{KOH}$ is one of

Received date: 2019-01-17; Modified date: 2019-03-04

Foundation item: National Natural Science Foundation of China (51572172, 51602332); Equipment Research Program (6140721050215); One-Hundred Talent Plan of Chinese Academy of Sciences

Biography: HE Wang-Tao(1994-), male, candidate of Master degree. E-mail: 1402250556@qq.com

Corresponding author: ZHU Yu-Fang, professor. E-mail: yfzhu@usst.edu.cn; 
the most common activating agents. The porous carbons obtained from $\mathrm{KOH}$ activation have a high SSA with considerable micro-pores ${ }^{[24]}$. Simultaneously, biomass derived carbons usually possess lots of macropores. Thus, $\mathrm{KOH}$ activated nitrogen-doped porous carbons always have well-developed hierarchical pore structure which could significantly enhance the transport of electrons ${ }^{[25]}$. Moreover, $\mathrm{KOH}$ activation process is also suitable for large scale production of porous carbons due to its mature technology and convenient operation. Compared with other activating reagents, $\mathrm{KOH}$ activation prefers to obtain porous carbons with high SSAs and lots of micro-pores.

Herein, we report a facile strategy of preparing $\mathrm{KOH}$ activated nitrogen-doped porous carbons using agriculture products potato as a precursor which possesses abundant nitrogen atoms and developed porous texture. The optimal catalyst NPC-750 obtains a high SSA of $1134 \mathrm{~m}^{2} \cdot \mathrm{g}^{-1}$ and a suitable nitrogen content of $1.57 \mathrm{at} \%$ which provides sufficient active sites for ORR electrocatalysis. Moreover, the well-defined hierarchical pore structure boosts the transport of ORR-relevant species. Their combination endows it outstanding ORR activity in an $\mathrm{O}_{2}$-saturated $0.1 \mathrm{~mol} \cdot \mathrm{L}^{-1} \mathrm{KOH}$ solution. It exhibits an onset potential of $0.89 \mathrm{~V}$ (vs. RHE) and a half-wave potential of $0.79 \mathrm{~V}$ (vs. RHE) which is comparable to most state-of-the-art non-metal catalysts for ORR in an alkaline media. In addition, it has only $12 \%$ degradation of current density after $5 \mathrm{~h}$ of ORR, indicating excellent long-time stability.

\section{Experimental}

\subsection{Synthesis of nitrogen-doped carbons (NCs)}

The nitrogen doped carbons ( $\mathrm{NCs}$ ) were prepared from biomass potato as a single carbon and nitrogen source. Typically, a steamed potato was grounded into mashed potatoes and then dried in an oven at $60{ }^{\circ} \mathrm{C}$. Subsequently, $3 \mathrm{~g}$ dried mashed potatoes were put into a porcelain boat, and transferred to the tube furnace, followed by carbonization under argon atmosphere at $900{ }^{\circ} \mathrm{C}$ for $2 \mathrm{~h}$ with a heating rate of $5{ }^{\circ} \mathrm{C} \cdot \mathrm{min}^{-1}$. The final product was named as nitrogen-doped carbons ( $\mathrm{NCs}$ ).

\subsection{Synthesis of nitrogen-doped porous car- bons (NPCs)}

NPCs were synthesized via chemical activation of $\mathrm{NCs}$ using $\mathrm{KOH}$ as activating reagent. For instance, $3 \mathrm{~g}$ $\mathrm{KOH}$ was dissolved in $50 \mathrm{~mL}$ deionized water, and $1 \mathrm{~g}$ $\mathrm{NC}$ was added into the $\mathrm{KOH}$ solution followed by stirring for $30 \mathrm{~min}$ to ensure uniform dispersion. After drying at $80{ }^{\circ} \mathrm{C}$, the black powder was annealed in argon atmosphere at 700,750 and $800{ }^{\circ} \mathrm{C}$ for $1 \mathrm{~h}$ with a heating rate of $3{ }^{\circ} \mathrm{C} \cdot \mathrm{min}^{-1}$, respectively. Finally, the product was washed by $1 \mathrm{~mol} \cdot \mathrm{L}^{-1} \mathrm{HCl}$ solution and deionized water for several times in order to remove residual $\mathrm{KOH}$ and other impurities. The final products were donated as NPC- $x$ ( $x$ means the activating temperature, ${ }^{\circ} \mathrm{C}$ ).

\subsection{Characterization}

The morphologies of samples were characterized by using scanning electron microscopy (SEM, Magellan 400) at an accelerating voltage of $2 \mathrm{kV}$. The transmission electron microscopy (TEM, JEM-2100F) was carried out at an accelerating voltage of $200 \mathrm{kV}$. Raman spectra were recorded by Raman spectrometer (LABRAM HR800). The pore structure properties of samples were studied by ASAP 2010 instrument with the nitrogen adsorption temperature of $77 \mathrm{~K}$. The specific surface area was calculated from the Brunner-Emmett-Teller (BET) method. The X-ray photoelectron spectroscopy (XPS) was investigated on the X-ray photoelectron spectrometer (ESCALAB 250).

\subsection{Electrochemical characterization}

The electrochemical properties of samples were performed on an electrochemical station of bipotentiostat (Pine instrument Co. LTD. USA). The electro-catalytic ORR performance was measured in a three-electrode system using a saturated calomel electrode (SCE) as reference electrode and a Pt plate as counter electrode in $\mathrm{O}_{2}$-saturated $0.1 \mathrm{~mol} \cdot \mathrm{L}^{-1} \mathrm{KOH}$ aqueous solution. Working electrode was the glassy carbon electrode coated with catalyst ink. Typically, $5 \mathrm{mg}$ samples and $20 \mu \mathrm{L}$ Nafion $(5 \mathrm{wt} \%)$ were dispersed into the solution containing $500 \mu \mathrm{L}$ deionized water and $500 \mu \mathrm{L}$ ethanol followed by ultrasonic treatment for $1 \mathrm{~h}$ to form homogenous ink. Subsequently, $20 \mu \mathrm{L}$ ink was dropped on the surface of glassy carbon electrode, followed by drying to form the working electrode. Electrochemical measurements including cyclic voltammetry (CV), rotating disk electrode (RDE) and rotating ring-disk electrode (RRDE) were tested at a potential range from -1.0 to $0.1 \mathrm{~V}$ (vs. SCE).

\section{Results and discussion}

The morphology of as-prepared samples was characterized by SEM and TEM. As shown in Fig. 1(a), the SEM image of NC particle reveals a smooth surface with a few small holes. After subjecting the subsequent activation by $\mathrm{KOH}(\mathrm{NC} / \mathrm{KOH}=1 / 3)$, the smooth surface became rough and porous, as evidenced by increased density of small holes on the surface which resulted from the combination of micropores. Moreover, the porous structure especially in the range of nanoscales of NPC particles 

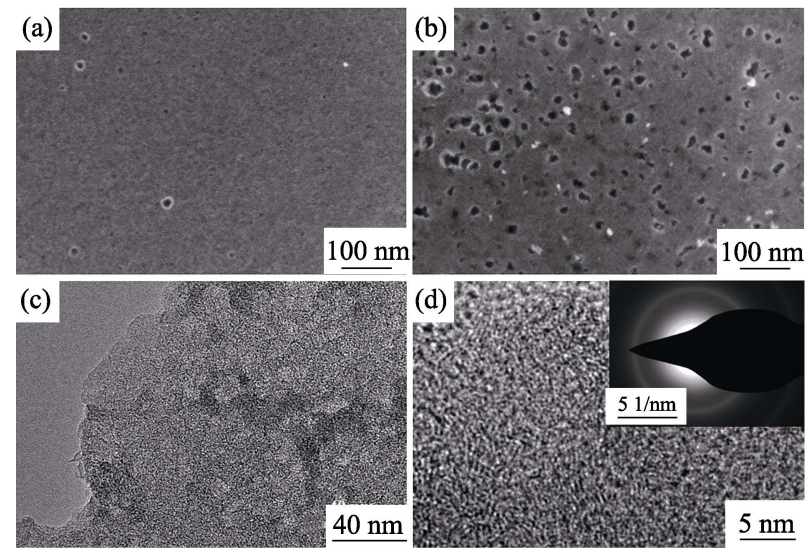

Fig. 1 SEM images of (a) NC and (b) NPC-750; (c) TEM and (d) HRTEM images of NPC-750 (inset in (d): corresponding SAED pattern of NPC-750)

was more obvious with the activating temperature increasing (Fig. 1(b)). TEM image of NPC-750 in Fig. 1(c) also shows the existence of large amount of pores within carbon matrix. Such a porous texture is beneficial for mass transfer during ORR, thereby improving the electrocatalytic performance of $\mathrm{NPCs}^{[26]}$. In addition, the HRTEM image in Fig. 1(d) as well as the SAED (inset in Fig. 1(d)) reveals the amorphous structure of the activated sample (NPC-750).

Raman spectra of NPCs in Fig. 2(a) exhibit two strong peaks located at about 1305 and $1596 \mathrm{~cm}^{-1}$. The peak at $1596 \mathrm{~cm}^{-1}$ ( $\mathrm{G}$ band) is attributed to $E_{2 \mathrm{~g}}$ mode of graphite and related to the vibration of $\mathrm{sp}^{2}$-bonded carbon atoms in a 2D hexagonal lattice, while the peak at $1305 \mathrm{~cm}^{-1}$ (D band) corresponds to vibrations of carbon atoms with dangling bonds in plane terminations of disordered ${ }^{[27-28]}$. Therefore, the lower intensity ratio of $\mathrm{D}$ band to $\mathrm{G}$ band $\left(I_{\mathrm{D}} / I_{\mathrm{G}}\right)$ suggested higher graphitization degree of carbon materials. As we all know, $\mathrm{KOH}$ activation can generate a lot of micropores and defects into the carbon matrix ${ }^{[29]}$. As shown in Fig. 2(a), the higher $I_{\mathrm{D}} / I_{\mathrm{G}}$ values $(1.15-1.16)$ of NPCs activated by $\mathrm{KOH}$ reveals increasing defects in carbon frameworks compared with NCs $(\sim 1.01)$, which results in high porosity and surface area. The defects could act as adsorption and active sites during the ORR process, thus leading to enhanced ORR performance.

Fig. 2(b) exhibits the $\mathrm{N}_{2}$ adsorption and desorption isotherms of all samples. NCs prepared from direct carbonization of mashed potatoes have no obvious uptake of $\mathrm{N}_{2}$, suggesting its low porosity and specific surface area (SSA). However, the NPCs all show the type IV isotherms with $\mathrm{H} 3$ hysteresis loops at $0.4<p / p_{0}<1.0$, implying that micro-pores and mesopores both exist in the $\mathrm{NPCs}^{[30-31]}$. Moreover, SSA of all samples are listed in Table 1. NC has a lowest SSA of $15.8 \mathrm{~m}^{2} \cdot \mathrm{g}^{-1}$ as expected. After $\mathrm{KOH}$ activation, NPCs obtain a hierarchical
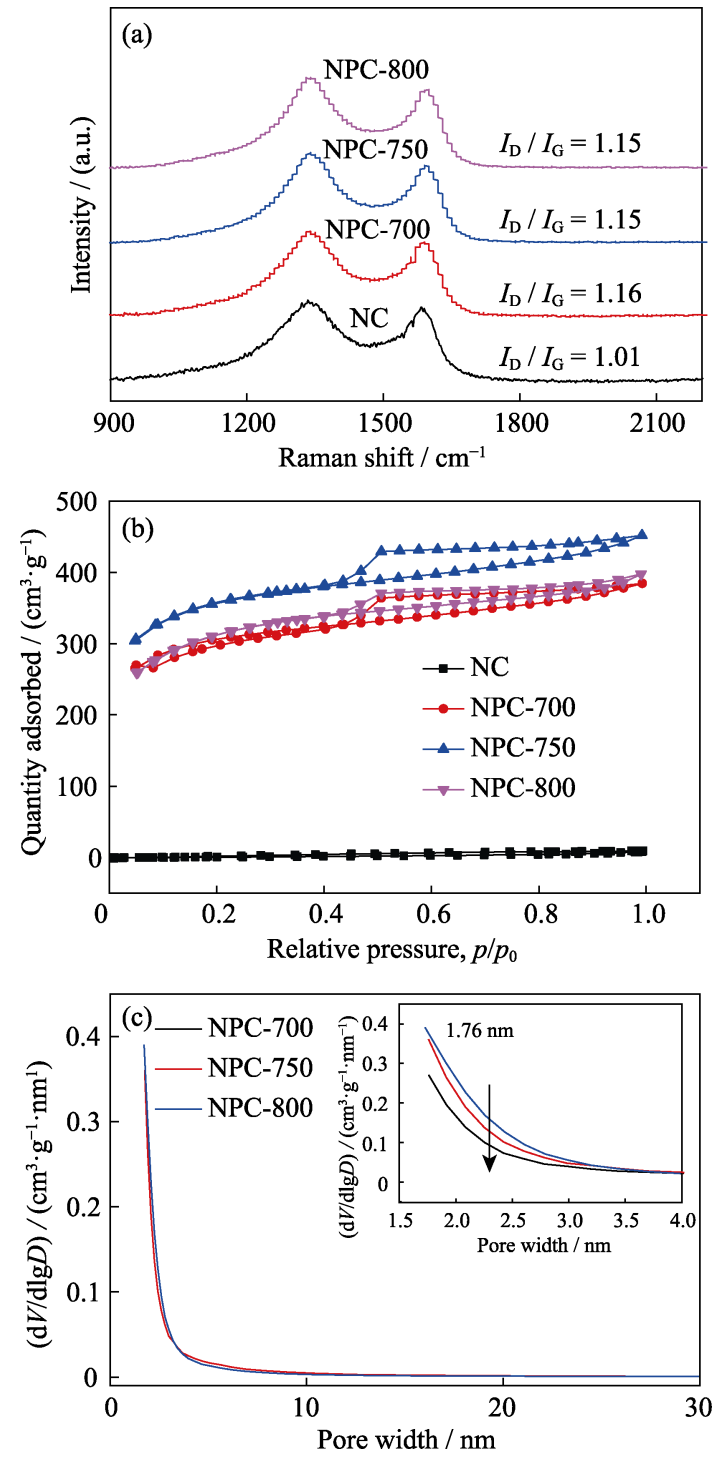

Fig. 2 (a) Raman spectra, (b) nitrogen adsorption-desorption isotherms and (c) pore size distribution curves of NPCs with inset in (c) showing the enlarged part

Table 1 Summary of porosity parameters of all samples

\begin{tabular}{cccc}
\hline Sample & $\mathrm{SSA} /\left(\mathrm{m}^{2} \cdot \mathrm{g}^{-1}\right)$ & $V_{\text {Total }} /\left(\mathrm{cm}^{3} \cdot \mathrm{g}^{-1}\right)$ & $R_{\text {pore }} / \mathrm{nm}$ \\
\hline NC & 15.8 & - & - \\
NPC-700 & 966.5 & 0.59 & 2.42 \\
NPC-750 & 1134.2 & 0.70 & 2.46 \\
NPC-800 & 1109.2 & 0.61 & 2.44 \\
\hline
\end{tabular}

micro-mesoporous structure, resulting in an improved SSA of 966.5 (NPC-700), 1134.2 (NPC-750) and $1109.2 \mathrm{~m}^{2} \cdot \mathrm{g}^{-1}$ (NPC-800), respectively. It is noted that the surface area of NPC-800 is slightly lower than the NPC-750, which reveals $750{ }^{\circ} \mathrm{C}$ is the optimal activating temperature. The pore size distribution curves (Fig. 2(c)) obtained using Barrett-Joyner-Halenda(BJH) method reveal average pore sizes of $2.42,2.46$ and $2.44 \mathrm{~nm}$ for NPC-700, NPC-750 and NPC-800, respectively. The inset in Fig. 2(c) reveals the change trends of pore size. The pore size 
slightly positively moved with the increasing temperature. Moreover, the existence of mesopores was possibly due to the combination of micropores, which is consistent with the result of SEM observation. This hierarchical porous structure resulted from $\mathrm{KOH}$ etching could facilitate the ORR process, while the micropores can provide sufficient contact area between electrode and electrolyte, and the mesopores can serve as the diffusion channel of electrolyte ions. Therefore, the nitrogendoped porous carbon (NPC-750) with high surface area and porosity is expected to exhibit satisfying ORR activity. In addition, the impact of the $\mathrm{KOH} /$ carbon mass ratio on the SSA was also investigated. Larger SSA was obtained by increasing the amount of $\mathrm{KOH}$.

As shown in Fig. 3(a), XPS spectra reveals the different composition of surface atoms for all of the samples. Peaks located at 285, 400, $532 \mathrm{eV}$ suggest $\mathrm{C} 1 \mathrm{~s}, \mathrm{~N} 1 \mathrm{~s}$ and $\mathrm{O} 1 \mathrm{~s}$, respectively ${ }^{[32]}$, and the $\mathrm{N}$ contents of NPCs de- creases with increasing temperature because the $\mathrm{KOH}$ activation could lead to the loss of the doped heteroatoms. Moreover, the NPC-750 has a most suitable N content of $1.57 \mathrm{at} \%$ which could provide sufficient active sites for ORR process. The high resolution N1s spectra of NPCs (Fig. 4(b-d)) can be deconvoluted into four peaks at $398.77,399.7,401.58$ and $403.69 \mathrm{eV}^{[33-36]}$, which can be assigned to pyridinic $\mathrm{N}$, pyrrolic $\mathrm{N}$, graphitic $\mathrm{N}$ and oxidized nitrogen species $\left(\mathrm{N}-\mathrm{O}_{x}\right)$, respectively. As we all know, $\mathrm{KOH}$ activation could destroy the graphene layer and expose more edges in the carbon framework. Furthermore, pyridinic and pyrrolic $\mathrm{N}$ atoms bonded with two $\mathrm{sp}^{2}$ carbon atoms will contribute electron lone pairs into carbon conjugated systems, consequently inducing electron donor effects. On the other side, graphitic $\mathrm{N}$ atoms take the position inside an aromatic ring with $\mathrm{sp}^{2}$ hybridization could further enhance the electrical conductivity of the carbon material (Fig. 3(f)). Therefore,
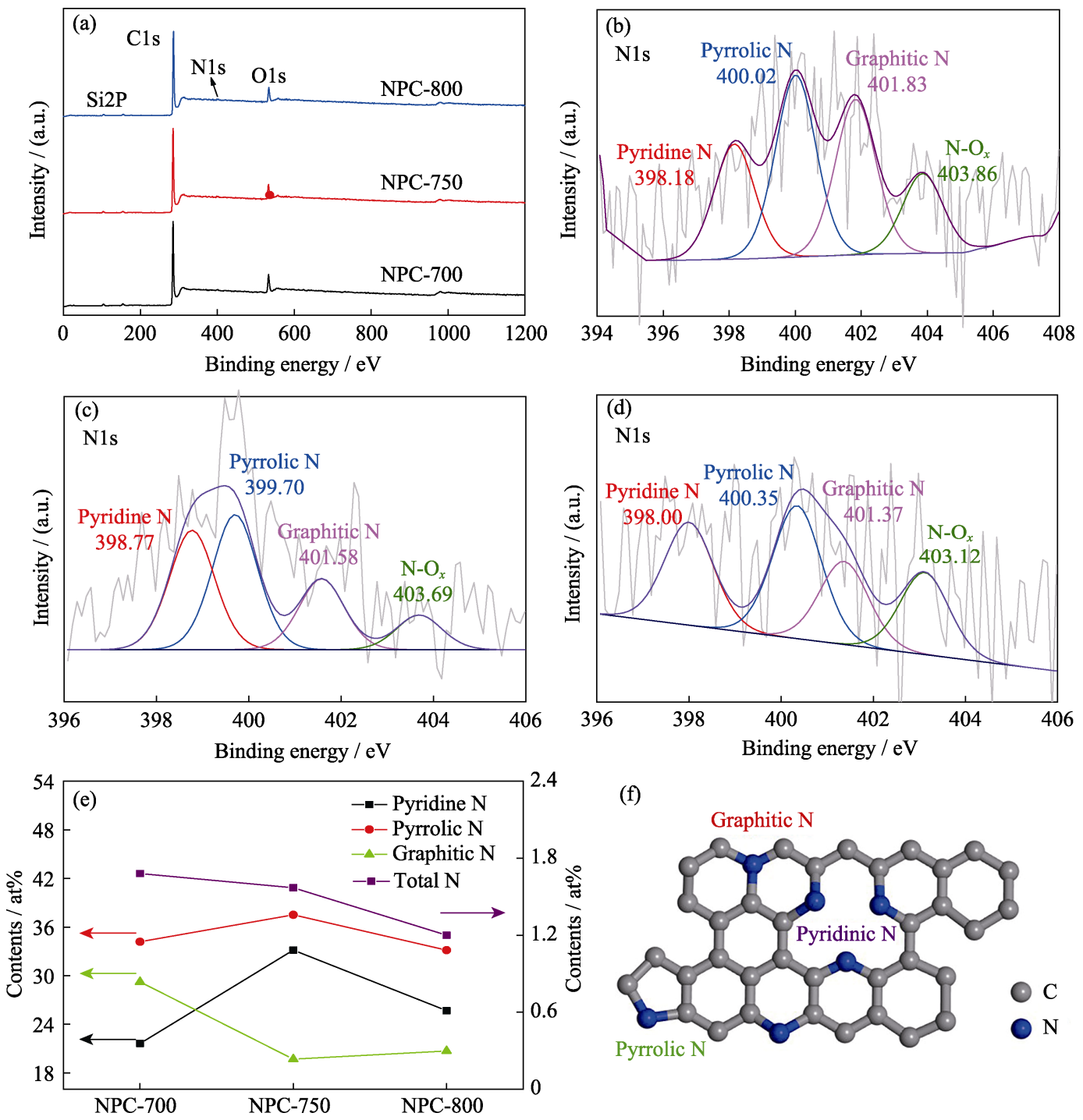

(f)

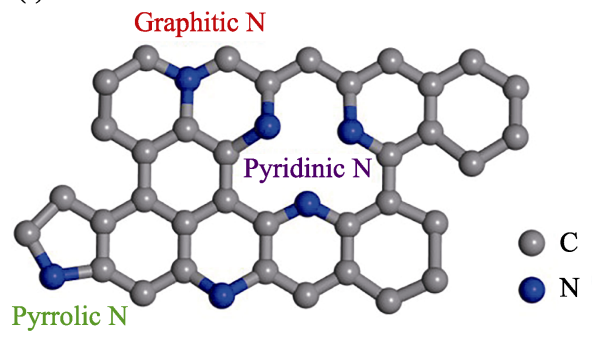

Fig. 3 (a) XPS survey spectra of NPCs, high resolution N 1s spectra of (b) NPC-700, (c) NPC-750 and (d) NPC-800;

(e) Contents of pyridinic N, graphitic N and pyrrolic N for NPCs at different activation temperature;

(f) Illustration of three types of nitrogen in NPCs 
improved ORR performance is expected for NPC-750 due to its sufficient pyridinic $\mathrm{N}$ content of $33.2 \mathrm{at} \%$ and suitable graphitic $\mathrm{N}$ content of 19.7 at $\%$ (Fig. 3(e)). Moreover, the existence of $\mathrm{O}$ functionalities could enable participation in Faradaic reactions and the combined effect between $\mathrm{N}$ and $\mathrm{O}$ groups is also beneficial for capacitance enhancement ${ }^{[37-38]}$.

The ORR activity and four electron selectivity of all samples were investigated by rotating disk electrode (RDE) and rotating ring disk electrode (RRDE) in a three-electrode system, respectively. Fig. 4(a) shows CV curves of NPC-750 in $0.1 \mathrm{~mol} \cdot \mathrm{L}^{-1} \mathrm{O}_{2}$ or $\mathrm{N}_{2}$ saturated $\mathrm{KOH}$ aqueous solution. An evident peak was obtained in $\mathrm{O}_{2}$ saturated electrolyte, while it disappeared in $\mathrm{N}_{2}$ saturated electrolyte at the same conditions, suggesting the obvious ORR occurred on the electrode. As shown in Fig. 4, the linear sweep voltammetry (LSV) curves at the rotating speed of $1600 \mathrm{r} \cdot \mathrm{min}^{-1}$ for all samples were recorded. NC shows poor activity for ORR as expected due to its low SSA and low porosity which limit the exposure of the surface active sites. In contrast, the enhanced ORR activity with the increase of activating temperature for NPCs was observed, indicating that more nanopores introduced by $\mathrm{KOH}$ activation in carbon matrix lead to larger SSA and porosity. However, it shows a dramatically decrease of ORR activity owing to the absence of nitrogen while the temperature exceeds $800{ }^{\circ} \mathrm{C}$. Therefore, NPC-750 $(\mathrm{KOH} /$ carbon=3/1) exhibits the best catalytic performance for ORR with a positive onset potential of $0.89 \mathrm{~V}$ (vs. RHE) and half-wave potential of
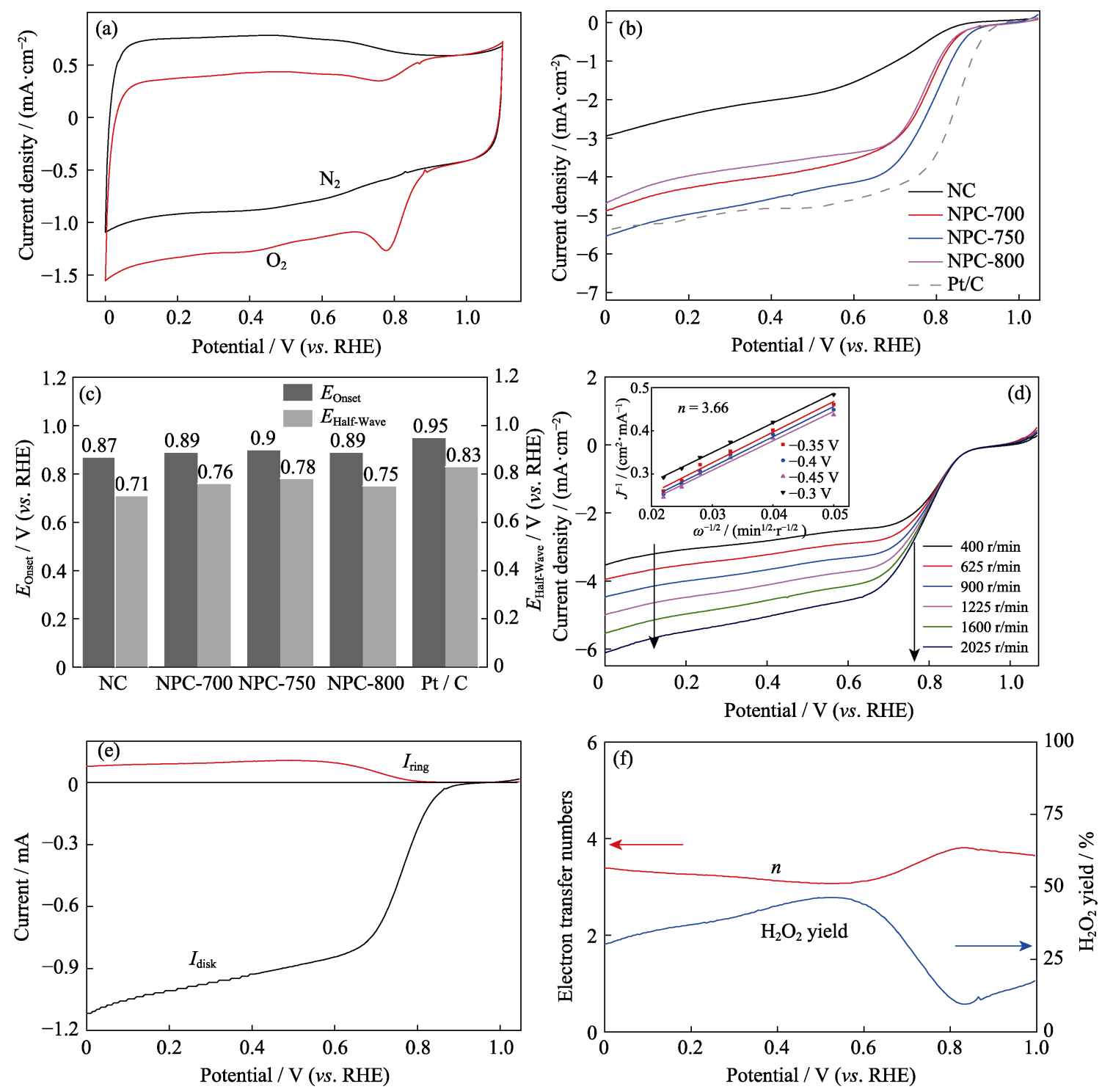

Fig. 4 (a) CV curves of NPC-750 in $\mathrm{N}_{2}$ and $\mathrm{O}_{2}$-saturated electrolyte; (b) LSV curves of all samples at $1600 \mathrm{r} \cdot \mathrm{min}^{-1}$; (c) Bar plots of $E_{\text {Onset }}$ and $E_{\text {Half-Wave }}$ for all samples; (d) LSV curves of NPC-750 at different rotating rates from 400 to $2025 \mathrm{r} \cdot \mathrm{min}^{-1}$ with inset showing the corresponding Kouteckey-Levich plots at different potentials; (e) RRDE polarization curves of NPC-750 at $1600 \mathrm{r} \cdot \mathrm{min}^{-1}$; (f) Electron transfer number and hydrogen peroxide yield of NPC-750

ORR performance was recorded in $0.1 \mathrm{~mol} \cdot \mathrm{L}^{-1} \mathrm{KOH}$ solution 
$0.79 \mathrm{~V}$ (vs. RHE) (Fig. 4(c)). The limited current density of NPC-750 also reaches $5.53 \mathrm{~mA} \cdot \mathrm{cm}^{-2}$, indicating a higher density of surface active sites as well as the best ORR performance. Simultaneously, the $\mathrm{KOH} / \mathrm{carbon}$ mass ratio dependent activity for NPCs catalyst was also determined. When the $\mathrm{KOH} /$ carbon mass ratio keeps 3, the NPC-700 shows the best ORR performance.

The four electron selectivity of NPCs catalyst was evaluated by Koutechy-Levich(K-L) equation and RRDE measurement ${ }^{[39-40]}$. Fig. 4(d) shows the LSV curves of NPC-750 at different rotating speeds from 400 to $2025 \mathrm{r} \cdot \mathrm{min}^{-1}$. Obviously, the increased current density was observed as the enhanced rotating speed due to the shortened diffusion layer for electrode material. Furthermore, the electron transfer number of NPC-750 calculated by the K-L equation is 3.66 (inset in Fig. 4(d)), indicating the ORR process mainly transformed through a four electron pathway which is important for fuel cells, because peroxides produced by a two-electron process could poison the cells via corroding the membrane and catalyst layer ${ }^{[41-42]}$. As shown in Fig. 4(e-f), the RRDE measurement was also taken to comprehend the reaction pathway of NPC-750. The ring current is close to zero, implying its weak selectivity of two electron pathway for ORR. The electron transfer numbers $(n)$ is $3.08-3.81$ at a potential range of $0-1.0 \mathrm{~V}$ ( $v s$. RHE) and the hydrogen peroxide yield is $9.5 \%-45.2 \%$. It suggests that the ORR process catalyzed by NPC-750 is a combination of two electron and four electron reaction pathway, although the four electron process is dominant.

The long-time stability is a key factor for excellent ORR catalysts. As shown in Fig. 5(a), after 5 h of ORR process, there are $88 \%$ of the initial current remained for NPC-750, which is far superior to $\mathrm{Pt} / \mathrm{C}$. Moreover, the methanol-tolerance capacity of NPC-750 was also evaluated (Fig. 5(b)). Pt/C suffered a dramatic decline of the current when $3 \mathrm{~mol} \cdot \mathrm{L}^{-1}$ methanol was added at $200 \mathrm{~s}$ during the chronoamperometric measurement. In contrast, a slight increase of the current was observed for NPC-750, indicating the excellent methanol-tolerance capacity which could meet the demands of the practical applications.

\section{Conclusions}

In summary, nitrogen-doped porous carbons were prepared from renewable nitrogen-rich potato by the direct pyrolysis process followed by $\mathrm{KOH}$ activation. High temperature pyrolysis leads to the outstanding electrical conductivity. The $\mathrm{KOH}$ activation treatment results in a high SSA and increased porosity, which could facilitate the mass transfer during ORR process. The high specific surface area of $1134.2 \mathrm{~m}^{2} \cdot \mathrm{g}^{-1}$, hierarchical porous structure
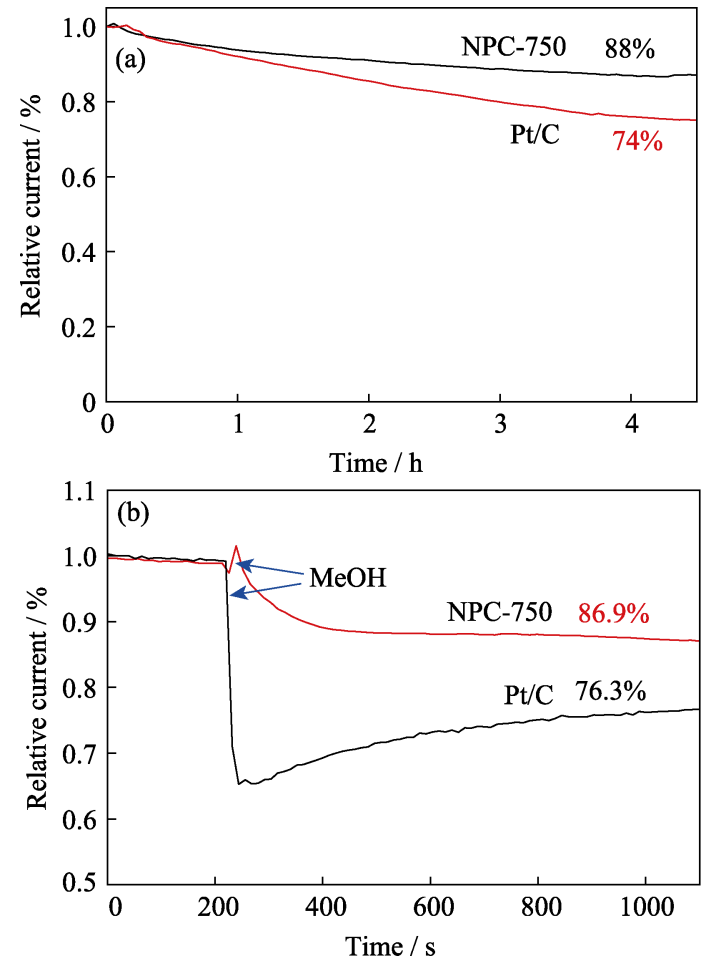

Fig. 5 (a) Long-time stability, (b) methanol-tolerance capacity of NPC-750 and $\mathrm{Pt} / \mathrm{C}$ in $0.1 \mathrm{~mol} \cdot \mathrm{L}^{-1} \mathrm{KOH}$ solution

and moderate nitrogen content of 1.57 at $\%$ make NPC750 own an excellent oxygen reduction reaction performance. It shows a positive onset potential of $0.89 \mathrm{~V}$ (vs. RHE) and half-wave potential of $0.79 \mathrm{~V}$ (vs. RHE). The limited current density of NPC-750 reaches $5.53 \mathrm{~A} \cdot \mathrm{cm}^{-2}$. Furthermore, NPC-750 exhibits superior long-time stability and methanol-tolerance capacity to commercial $\mathrm{Pt} / \mathrm{C}$ catalyst, implying that potato-derived NPC-750 has great potential as an excellent catalyst for oxygen reduction reaction in the future practical applications.

\section{References:}

[1] GUO DA-KAI, TIAN ZHENG-FANG, WANG JIA-CHENG, et al. $\mathrm{Co}_{2} \mathrm{~N}$ nanoparticles embedded $\mathrm{N}$-doped mesoporous carbon as efficient electrocatalysts for oxygen reduction reaction. Applied Surface Science, 2019, 473: 555-563.

[2] KIM SEOK-JIN, MAHMOOD JAVEED, KIM CHANG-MIN, et al. Defect-free encapsulation of $\mathrm{Fe}(0)$ in $2 \mathrm{D}$ fused organic networks as a durable oxygen reduction electrocatalyst. Journal of the American Chemical Society, 2018, 140(5): 1737-1742.

[3] HAN YUN-HU, WANG YANG-GANG, CHEN WEN-XING, et al. Hollow N-doped carbon spheres with isolated cobalt single atomic sites: superior electrocatalysts for oxygen reduction. Journal of the American Chemical Society, 2017, 139(48): 17269-17272.

[4] ZHANG LONG-ZHOU, JIA YI-ALEC, YAN XUE-CHENG, et al. Coordination of atomic Co-Pt coupling species at carbon defects as active sites for oxygen reduction reaction. Journal of the American Chemical Society, 2018, 140(34): 10757-10763.

[5] HE DA-PING, ZHANG LI-BO, HE DONG-SHENG, et al. Amorphous nickel boride membrane on a platinum-nickel alloy surface for enhanced oxygen reduction reaction. Nature Communication, 2016, 7: 12362. 
[6] ZHANG YA-QING, ZHANG XIAN-LEI, MA XIU-XIU, et al. A facile synthesis of nitrogen-doped highly porous carbon nanoplatelets: efficient catalysts for oxygen electroreduction. Scientific Reports, 2017, 7: 43366.

[7] LIANG HAI-WEI, WE WEI, WU ZHONG-SHUAI, et al. Mesoporous metal-nitrogen-doped carbon electrocatalysts for highly efficient oxygen reduction reaction. Journal of the American Chemical Society, 2013, 135(43): 16002.

[8] ZHOU TING-SHENG, ZHOU YAO, MA RU-GUANG, et al. In situ formation of nitrogen-doped carbon nanoparticles on hollow carbon spheres as efficient oxygen reduction electrocatalysts. Nanoscale, 2016, 8(42): 18134-18142.

[9] GUO DA-KAI, HAN SAN-CAN, WANG JIA-CHENG, et al. MIL-100-Fe derived $\mathrm{N}$-doped $\mathrm{Fe} / \mathrm{Fe}_{3} \mathrm{C} @ \mathrm{C}$ electrocatalysts for efficient oxygen reduction reaction. Applied Surface Science, 2018, 434: 1266-1273.

[10] WEI WEI, LIANG HAI-WEI, PARVEZ KHALED, et al. Nitrogendoped carbon nanosheets with size-defined mesopores as highly efficient metal-free catalyst for the oxygen reduction reaction. Angewandte Chemie International Edition, 2014, 53(6): 1570-1574.

[11] WEI JING, LIANG YAN, HU YAP-XIN, et al. A versatile irontannin-framework ink coating strategy to fabricate biomass-derived iron carbide/Fe-N-carbon catalysts for efficient oxygen reduction. Angewandte Chemie International Edition, 2016, 55(4): 1355-1359.

[12] LIU XIAO-JUN, ZHOU YU-CHENG, ZHOU WEI-JIA, et al. Biomass-derived nitrogen self-doped porous carbon as effective metal-free catalysts for oxygen reduction reaction. Nanoscale, 2015, 7(14): 6136-6142.

[13] CHEN PING, WANG LI-KUN, WANG GAN, et al. Nitrogendoped nanoporous carbon nanosheets derived from plant biomass: an efficient catalyst for oxygen reduction reaction. Energy \& Environmental Science, 2014, 7(12): 4095-4103.

[14] WAN WEI, WANG QIANG, ZHANG LI, et al. N-, P- and Fe-tridoped nanoporous carbon derived from plant biomass: an excellent oxygen reduction electrocatalyst for zinc-air batteries. Journal of Materials Chemistry A, 2016, 4(22): 8602-8609.

[15] GAO SHU-YAN, CHEN YAN-LI, FAN HAO, et al. Large scale production of biomass-derived $\mathrm{N}$-doped porous carbon spheres for oxygen reduction and supercapacitors. Journal of Materials Chemistry A, 2014, 2(10): 3317.

[16] GU DA-GUO, ZHOU YAO, MA RU-GUANG, et al. Facile synthesis of $\mathrm{N}$-doped graphene-like carbon nanoflakes as efficient and stable electrocatalysts for the oxygen reduction reaction. Nanomicro Letters, 2018, 10(2): 29.

[17] ZHANG MAN, JIN XIN, WANG LI-NAN, et al. Improving biomassderived carbon by activation with nitrogen and cobalt for supercapacitors and oxygen reduction reaction. Applied Surface Science, 2017, 411: 251-260.

[18] LIN GAO-XIN, MA RU-GUANG, ZHOU YAO, et al. KOH activation of biomass-derived nitrogen-doped carbons for supercapacitor and electrocatalytic oxygen reduction. Electrochimica Acta, 2018, 261: 49-57.

[19] XING RUO-HAO, ZHOU TING-SHENG, ZHOU YAO, et al. Creation of triple hierarchical micro-meso-macroporous N-doped carbon shells with hollow cores toward the electrocatalytic oxygen reduction reaction. Nano-micro Letters, 2018, 10(1): 3 .

[20] PEZOTI OSVALDO, CAZETTA ANDRE-L, SOUZA ISIS-P A F, et al. Adsorption studies of methylene blue onto $\mathrm{ZnCl}_{2}$-activated carbon produced from buriti shells (Mauritia flexuosa L.). Journal of Industrial and Engineering Chemistry, 2014, 20(6): 4401-4407.

[21] WANG BIN, QIU JIAN-HUI, FENG HUI-XIA, et al. KOHactivated nitrogen doped porous carbon nanowires with superior performance in supercapacitors. Electrochimica Acta, 2016, 190: 229-239.

[22] SHAMSUDDIN M S, YUSOFF N R N, SULAIMAN M A. Synthesis and characterization of activated carbon produced from kenaf core fiber using $\mathrm{H}_{3} \mathrm{PO}_{4}$ activation. Procedia Chemistry, 2016, 19: 558-565.

[23] NAN DING, WANG JIAN-GAN, HUANG ZHENG-HONG, et al. Highly porous carbon nanofibers from electrospun polyimide/ $\mathrm{SiO}_{2}$ hybrids as an improved anode for lithium-ion batteries. Electrochemistry Communications, 2013, 34: 52-55.

[24] WANG JIA-CHENG, KASKAL STEFAN. KOH activation of carbonbased materials for energy storage. Journal of Materials Chemistry, 2012, 22(45): 23710.

[25] DUTTA SAIKAT, BHAUMIK ASIM, WU KELVIN C W. Hierarchically porous carbon derived from polymers and biomass: effect of interconnected pores on energy applications. Energy \& Enviromental Science, 2014, 7(11): 3574-3592.

[26] ZHANG LIN-JIE, SU ZI-XUE, JIANG FEI-LONG, et al. Highly graphitized nitrogen-doped porous carbon nanopolyhedra derived from ZIF-8 nanocrystals as efficient electrocatalysts for oxygen reduction reactions. Nanoscale, 2014, 6(12): 6590-602.

[27] ZHOU HUANG, ZHANG JIAN, AMIINU IBRAHIM SAANA, et al. Transforming waste biomass with an intrinsically porous network structure into porous nitrogen-doped graphene for highly efficient oxygen reduction. Physical Chemistry Chemical Physics, 2016, 18(15): 10392-10399.

[28] CHEN YU-ZHEN, WANG CHENG-MING, WU ZHEN-YU, et al. From bimetallic metal-organic framework to porous carbon: high surface area and multicomponent active dopants for excellent electrocatalysis. Advanced Materials, 2015, 27(34): 5010-5016.

[29] QIE LONG, CHEN WEI-MIN, XU HENG-HUI, et al. Synthesis of functionalized 3D hierarchical porous carbon for high-performance supercapacitors. Energy \& Environmental Science, 2013, 6(8): 2497.

[30] LI MIN, LI WEI, LIU SHOU-XIN. Hydrothermal synthesis, characterization, and $\mathrm{KOH}$ activation of carbon spheres from glucose. Carbohydrate Research, 2011, 346(8): 999-1004.

[31] YU MIAO, LI JIAN, WANG LI-JUAN. KOH-activated carbon aerogels derived from sodium carboxymethyl cellulose for highperformance supercapacitors and dye adsorption. Chemical Engineering Journal, 2017, 310: 300-306.

[32] ZHOU TING-SHENG, MA RU-GUANG, ZHOU YAO, et al. Efficient $\mathrm{N}$-doping of hollow core-mesoporous shelled carbon spheres via hydrothermal treatment in ammonia solution for the electrocatalytic oxygen reduction reaction. Microporous and Mesoporous Materials, 2018, 261: 88-97.

[33] ZHOU TING-SHENG, ZHOU YAO, MA RU-GUANG, et al. Nitrogen-doped hollow mesoporous carbon spheres as a highly active and stable metal-free electrocatalyst for oxygen reduction. Carbon, 2017, 114: 177-186.

[34] ZHOU MIN, PU FAN, WANG ZHAO, et al. Nitrogen-doped porous carbons through $\mathrm{KOH}$ activation with superior performance in supercapacitors. Carbon, 2014, 68: 185-194.

[35] LIANG JI, JIAO YAN, JARONIEC MIETEK, et al. Sulfur and nitrogen dual-doped mesoporous graphene electrocatalyst for oxygen reduction with synergistically enhanced performance. Angewandte Chemie International Edition, 2012, 51(46): 11496-11500.

[36] ZHONG HAI-XIA, WANG JUN, ZHANG YU-WEI, et al. ZIF-8 derived graphene-based nitrogen-doped porous carbon sheets as highly efficient and durable oxygen reduction electrocatalysts. Angewandte Chemie International Edition, 2014, 53(51): 14235-14239.

[37] YANG MEI, ZHOU ZHEN. Recent breakthroughs in supercapaci- 
tors boosted by nitrogen-rich porous carbon materials. Advanced Science, 2017, 4(8): 1600408.

[38] MA YI-FAN, GUO QIU-BO, YANG MEI, et al. Highly doped graphene with multi-dopants for high-capacity and ultrastable sodiumion batteries. Energy Storage Materials, 2018, 13: 134-141.

[39] WU ZHONG-SHUAI, YANG SHU-BIN, SUN YI, et al. 3D nitrogendoped graphene aerogel-supported $\mathrm{Fe}_{3} \mathrm{O}_{4}$ nanoparticles as efficient electrocatalysts for the oxygen reduction reaction. Journal of the American Chemical Society, 2012, 134(22): 9082-9085.

[40] BING YONG-HONG, LIU HAN-SAN, ZHANG LEI, et al.
Nanostructured Pt-alloy electrocatalysts for PEM fuel cell oxygen reduction reaction. Chemical Society Reviews, 2010, 39(6): 2184-2202.

[41] ZHANG LI-PENG, XIA ZHEN-HAI. Mechanisms of oxygen reduction reaction on nitrogen-doped graphene for fuel cells. The Journal of Physical Chemistry C, 2011, 115(22): 11170-11176.

[42] LIN ZI-YIN, WALLER GORDON, LIU YAN, et al. Facile synthesis of nitrogen-doped graphene via pyrolysis of graphene oxide and urea, and its electrocatalytic activity toward the oxygen-reduction reaction. Advanced Energy Materials, 2012, 2(7): 884-888.

\title{
氢氧化钾活化制备可再生多孔碳及其电催化氧还原性能研究
}

\author{
何王涛 ${ }^{1,2}$, 马汝 $广^{2}$, 朱钰方 ${ }^{1}$, 杨明杰 ${ }^{3}$, 王家成 ${ }^{2}$
}

(1. 上海理工大学 材料科学与工程学院, 上海 200093 ; 2. 中国科学院 上海硅酸盐研究所, 高性能陶瓷和超微结 构国家重点实验室, 上海 200050; 3. 莫纳什大学 化学工程系, 维多利亚 3800, 澳大利亚)

摘 要: 氧还原反应缓慢的动力学过程严重限制了燃料电池的能量转换效率, 而商用 $\mathrm{Pt} / \mathrm{C}$ 催化剂成本太高、资源稀 缺、稳定性差, 需要寻找合适的材料来取代商用的 $\mathrm{Pt} / \mathrm{C}$ 催化剂。近年来, 氮掺杂多孔碳材料因其独特的物理和化 学特性吸引了大量的关注。本文使用富含氮元素的可再生土豆作为生物质前驱体, 通过简单的一步热解过程和 $\mathrm{KOH}$ 活化方法相结合制备出了一系列氮掺杂多孔碳电催化剂; 并系统研究了 $\mathrm{KOH}$ 用量和活化温度对碳基体孔结 构和电催化性能的影响。结果表明, 当活化温度为 $750{ }^{\circ} \mathrm{C} 、 \mathrm{KOH}$ 与碳的质量比为 $3 / 1$ 时, 所制备的催化剂(NPC-750) 的氧还原活性最高, 起始电位和半波电位分别达到 0.89 和 $0.79 \mathrm{~V}$ ( vs. RHE), 极限电流密度达到 $5.53 \mathrm{~mA} \cdot \mathrm{cm}^{-2}$ 。 NPC-750 优异的氧还原催化活性主要归因于其发达的孔结构、高的比表面积 $\left(1134.2 \mathrm{~m}^{2} \cdot \mathrm{g}^{-1}\right)$ 和合适的氮含量 (1.57at\%)。同时，优异的循环稳定性和抗甲醇中毒性能进一步说明这些生物多孔碳材料是潜在的低成本氧还原电催 化剂。此外, 这些高比表面积多孔碳在超级电容、吸附/分离、催化以及电池等领域也具有潜在的应用前景。

关 键 词: 生物质; 多孔; 氮掺杂碳; 氢氧化钾活化; 氧还原反应

中图分类号: TQ174 文献标识码: A 